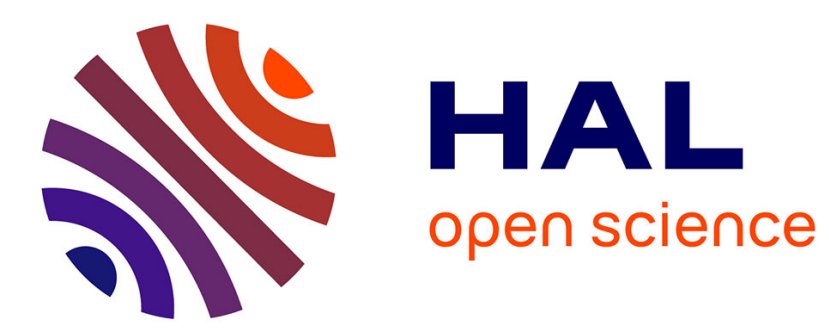

\title{
NEW COMPOUNDS OBTAINED BY LPCVD IN THE B-C-N CHEMICAL SYSTEM
}

F. Saugnac, F. Teyssandier, A. Marchand

\section{To cite this version:}

F. Saugnac, F. Teyssandier, A. Marchand. NEW COMPOUNDS OBTAINED BY LPCVD IN THE B-C-N CHEMICAL SYSTEM. Journal de Physique IV Proceedings, 1991, 02 (C2), pp.C2-673-C2-680. 10.1051/jp4:1991281 . jpa-00249871

\section{HAL Id: jpa-00249871 https://hal.science/jpa-00249871}

Submitted on 1 Jan 1991

HAL is a multi-disciplinary open access archive for the deposit and dissemination of scientific research documents, whether they are published or not. The documents may come from teaching and research institutions in France or abroad, or from public or private research centers.
L'archive ouverte pluridisciplinaire HAL, est destinée au dépôt et à la diffusion de documents scientifiques de niveau recherche, publiés ou non, émanant des établissements d'enseignement et de recherche français ou étrangers, des laboratoires publics ou privés. 
Colloque C2, suppl. au Journal de Physique II, Vol. 1, septembre 1991

\title{
NEW COMPOUNDS OBTAINED BY LPCVD IN THE B-C-N CHEMICAL SYSTEM
}

\author{
F. SAUGNAC ${ }^{*}$, F. TEYSSANDIER** ${ }^{*}$ and A. MARCHAND*** \\ *aEROSPATIALE AQUITAINE, BP 11, F-33165 saint Médard en Jalles \\ cedex, France \\ * "IMP CNRS, avenue de Villeneuve, F-66860 Perpignan cedex, \\ France \\ *** CRPP CNRS, Chateau Brivazac, avenue schweitzer, \\ F-33600 Pessac, France
}

\begin{abstract}
The composition and some physical properties of boroncarbon-nitrogen solid solutions prepared by chemical vapor deposition (CVD) have been investigated. Crystalline and amorphous films resulting from heterogeneous nucleation were characterized by X-ray diffraction, XPS, RBS and TEM. The compositions of these single-phase materials are concentrated in two domains located in the $\mathrm{B} / \mathrm{N}>1$ part of the $\mathrm{B}-\mathrm{C}-\mathrm{N}$ composition diagram. The carbon-rich domain corresponds to an ideal $\mathrm{C}_{5} \mathrm{~B}_{2} \mathrm{~N}$ composition.with various structural defects The thermal stability behavior of these films is characterized by the absence of any mass loss after 1 hour at $1700^{\circ} \mathrm{C}$ while graphitization and formation of small amounts of $\mathrm{B}_{13} \mathrm{C}_{2}$ are observed. Density and electrical conductivity measurements were also performed.
\end{abstract}

\section{I - INTRODUCTION}

The similarity of the crystalline structures of graphite and hexagonal boron nitride immediately suggests the possibility of obtaining solid solutions of these materials. Graphite being a black semi-metal and boron nitride a white insulator, interesting adjustable semiconducting properties could be expected for their "offspring".

Very little work has previously concerned such materials and most syntheses were carried out by chemical vapor deposition (CVD). The first results on these compounds were published in 1972 by Badzian et al.[1]. From the reaction of $\mathrm{B} \mathrm{BCl}_{3}-\mathrm{CCl}_{4}-\mathrm{H}_{2}-\mathrm{N}_{2}$ mixture with a carbon rod heated at $1950^{\circ} \mathrm{C}, 25 \mathrm{~nm}$ sized aggregates with graphite-like structure were obtained. The composition was not mentioned. BCN materials were deposited in 1980 by Diefendorf et al.[2]. The initial gas phase $\mathrm{BCl}_{3}-\mathrm{NH}_{3}-\mathrm{C}_{2} \mathrm{H}_{2}$ at high temperature $\left(1700^{\circ} \mathrm{C}\right)$ and under low pressure, led to $\mathrm{BCN}$ compounds which proved to be two-phased $\mathrm{BN}-\mathrm{C}$ mixtures as revealed by IR spectroscopy.

It was only in 1987 that Bartlett and coworkers published a paper [3] showing evidence of the existence of such solid solutions, which were studied from the point of view of their electrical conductivity some time later in a second publication [4]. The same precursors as Diefendorf were used with hydrogen as carrier gas but the temperature range of $400-700^{\circ} \mathrm{C}$ was far lower. XPS analysis of the black solid coating showed the existence of bonds between the 
three elements. Two compositions were determined by chemical analysis: $\mathrm{B}_{0.485} \mathrm{C}_{0.03} \mathrm{~N}_{0.485}$ and $\mathrm{B}_{0,35} \mathrm{C}_{0,30} \mathrm{~N}_{0,35}$. After annealing at $900^{\circ} \mathrm{C}$, the $\mathrm{X}$-ray diffraction patterns confirmed the layered hexagonal structure.

At the same time, and starting from the same boron and nitrogen precursors but with various hydrocarbons $\left(\mathrm{CH}_{4}, \mathrm{C}_{3} \mathrm{H}_{8}\right.$ or $\left.\mathrm{C}_{2} \mathrm{H}_{2}\right)$, Moore [5] obtained similar materials between 1500 and $1900^{\circ} \mathrm{C}$ under reduced pressure $(0,7-2$ torr). The diffractograms of the as-deposited samples are consistent with a single-phase mixture and chemical analysis accounts for the

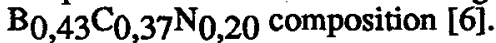

More recently, in an attempt to carry out a two-phase coating of " $\mathrm{B}_{4} \mathrm{C}$ "-BN from a $\mathrm{BCl}_{3}-\mathrm{NH}_{3}-\mathrm{CH}_{4}-\mathrm{H}_{2}$ mixture $\left(1377^{\circ} \mathrm{C}, 25\right.$ Torr), Besmann [7] obtained a single-phase deposit. AES analysis revealed a composition of $\mathrm{B}_{0,58} \mathrm{C}_{0,25} \mathrm{~N}_{0,17}$.

CVD is not the only way to prepare such materials and carbon films containing nitrogen and/or carbon can be generated by pyrolysis of appropriate precursors as shown by Maya et al. [8]. Starting from an aliphatic borazine precursor the film has a metallic appearance and presents graphitic features. Its chemically analysed composition is $\mathrm{B}_{0,28} \mathrm{C}_{0,37} \mathrm{~N}_{0,35}$.

All the compositions cited above, corresponding to $\mathrm{BxCyNz}$ graphite-like structures are plotted on Figure 1.

The method of preparation of our samples was the same as that used by Bartlett et al [3] , i.e. CVD from a mixture of acetylene, ammonia, and boron trichloride, but various carrier-gases (nitrogen, helium, hydrogen) and a generally higher deposition temperature (900 $1050^{\circ} \mathrm{C}$ ) were used. The detailed process and reaction mechanisms are described elsewhere as well as the morphology of the deposits [9]. We obtained very smooth thin films (a few tens of micrometers thick) with a strong reflectivity, resulting from a heterogeneous reaction on the substrate (graphite or silica platelets). The composition, structure, and some properties of these materials are presented in this paper.

The composition values given below result from X-ray microprobe analysis of the films. No elements other than $\mathrm{C}, \mathrm{B}, \mathrm{N}, \mathrm{O}$ were found in significant quantities in the samples . The structural studies were performed by X-ray diffraction. A more complete picture of the chemical bonds was obtained by X-ray photoelectron spectroscopy (XPS).

The stability studies were conducted in a graphite resistance furnace, under a flow of nitrogen up to $1700^{\circ} \mathrm{C}$ and a flow of argon above that temperature. The electrical resistance of the films was measured by the four point probe technique at temperatures between 77 and 300 K.

\section{II - CHARACTERIZATION OF THE FILMS}

\section{(1) Composition and homogeneity}

Although the deposition temperature for the films was always $1000^{\circ} \mathrm{C}$ or $1050^{\circ} \mathrm{C}$, varying deposition parameters (e.g. gas flow rate, gas composition, pressure, etc...) could yield samples with quite varied compositions. The composition can easily be represented in a triangular diagram, with pure carbon, pure boron, and pure nitrogen located at the corners.(Figure 1). A limited number of studies by the Rutherford back scattering (RBS) technique and by Auger electron spectroscopy (AES) allowed us to confirm that the films are homogeneous and that, if any oxygen is found, it is located at the surface of the samples $(50 \mathrm{~nm})$ and can be considered as surface contamination.

Two remarkable facts emerge immediately from an examination of Figure 1: the $\mathrm{B} / \mathrm{N}$ ratio is always greater than 1 and quite often above 2 , and the film compositions are restricted to two small domains, $\mathrm{C}$ and $\mathrm{A}$, (more than $60 \%$ carbon in $\mathrm{C}$, and less than 45 at\% in A), both with less than 50 at\% boron. Moreover, the compositions in domain C actually tend to gather around a "focal point" corresponding approximately to 62,5 at $\%, 25$ at $\%$ B, and 12,5 at $\% \mathrm{~N}$, or to a rough "formula" $\mathrm{C}_{5} \mathrm{~B}_{2} \mathrm{~N}$.

This domain extends towards the binary $\mathrm{B}-\mathrm{C}$ composition diagram on which it is limited by the compositions $\mathrm{BC}_{3}$ and $\mathrm{BC}_{6}$ according to Bartlett [10]. 


\section{(2) X-ray diffraction}

Figures 2 and 3 show typical diffractograms of deposits from the $C$ and $A$ domains. These diagrams are clearly those of solid solutions since they cannot be resolved into separate diffractograms of BN and carbon. But they are strikingly different from one another. Both types of material exhibit a graphitic turbostratic structure, with no three-dimensional order (unresolved (100) and (101) peaks). But the A diffractogram (Figure 2) shows a strong intensity of the small angle scattering, while no such feature appears in Figure 3. Similarly, the very wide (002) diffraction line and the $\mathrm{d}_{002}$ distance $(0,368 \mathrm{~nm})$ of the A material contrast with the short $\mathrm{d}_{002}$ value $(0,338 \mathrm{~nm})$ and sharp line of the $C$ film, where the corresponding coherence length, $\mathrm{L}_{c}$, can be estimated to be $20 \mathrm{~nm}$. These observations show that in contrast to the A films, the $\mathrm{C}$ materials have a well-developed crystalline order. Roughly speaking the A deposits can indeed be qualified as "amorphous" and the $C$ films as "crystalline". As a matter of fact the two-dimensional organization of the $\mathrm{C}$ materials is actually more extensive than that of pure pyrolytic carbons deposited at the same temperature $\left(\mathrm{L}_{c}\right.$ between 3 and $8 \mathrm{~nm}$, and $\mathrm{d}_{002}$ from 0,342 to $0,346 \mathrm{~nm}$ ) [11]. It is even more developed than the two-dimensional structure of graphitizable pyrocarbons heat-treated at $2000^{\circ} \mathrm{C}$.

\section{(3) X-ray Photoelectron Spectroscopy (XPS)}

A good deal of caution is necessary when using XPS spectra for a quantitative chemical analysis of deposits, since this technique is very sensitive to surface pollution of the samples. However, it is a very efficient tool for determining the types of bonding involving each element. This is the way we have used it in the present study the detailed results of which will be published [12].

This study has shown that spectra of a typical A deposit or a typical $\mathrm{C}$ film is not the spectra of two-phase mixtures of carbon and boron nitride, which would consist only of the BN peaks for the $B$ and $N$ atoms and of the $C$ peak of the $C$ atom. The observed spectra are clearly composite peaks for each type of atom, and they are evidence of the existence of the CBN solid solutions. The $\mathrm{C}$ spectrum always shows either a $\mathrm{C}-\mathrm{N}$ or a $\mathrm{C}-\mathrm{B}$ component (or both) on the sides of the main C-C peak (284,4 eV).The B spectrum always presents a component with a shift of $-1.8 \mathrm{eV}$ on the side of the $\mathrm{BN}$ peak $(189,8 \mathrm{eV})$ and the $\mathrm{N}$ spectrum always consists of the main NB (398 eV) peak and a higher energy component $(\mathrm{N}-\mathrm{C})$ shifted by about $+1.3 \mathrm{eV}$. Table 1 gives a general description of these XPS findings. A very interesting feature is the intense component of the $B$ peak shifted $-1.8 \mathrm{eV}$ from the $\mathrm{B}-\mathrm{N}$ reference, which on first sight, cannot be interpreted from the available literature. It must be remembered that in a graphitic type lattice each atom has three close neighbors and that the corresponding XPS shift depends on the overall electronegativity of this environment. A positive neighbor may compensate for a negative one. It is known that the $\mathrm{B}$ peak of a boron with three $B$ neighbors $\left(B_{3}\right)$ is shifted $-4 \mathrm{eV}$ from the $\left(\mathrm{BN}_{3}\right)$ reference position, while a $\left(\mathrm{BC}_{3}\right)$ peak is only shifted $-2.5 \mathrm{eV}$. A shift of $-1.8 \mathrm{eV}$ may then correspond either to a $\left(\mathrm{BCN}_{2}\right)$ or to a $\left(\mathrm{BNC}_{2}\right)$ type boron, most likely $\left(\mathrm{BNC}_{2}\right)$ since it is closer to $\left(\mathrm{BC}_{3}\right)$ than to $\left(\mathrm{BN}_{3}\right)$.

We have opted for this interpretation and conclude that a large proportion of the boron atoms are surrounded by two $\mathrm{C}$ and one $\mathrm{N}$, with the following grouping.<smiles>CB(C)N</smiles>

A similar reasoning led us to conclude that the nitrogen peak on the high energy side of the reference $\left(\mathrm{NB}_{3}\right)$ peak corresponds to a $\left(\mathrm{NCB}_{2}\right)$ or a $\left(\mathrm{NBC}_{2}\right)$ group since it is located between the $\left(\mathrm{NB}_{3}\right)$ and $\left(\mathrm{NC}_{3}\right)(+2.5 \mathrm{eV})$ positions.

\section{(4) Suggested structures}

The above results enable us to suggest structures for the various films of domains $\mathrm{C}$ 
and $A$, more specifically for the two-dimensional graphitic-type layers which constitute their turbostratic, stacking taking into account the theoretical study of A Y Liu [13].

We accordingly looked for an organization of the $\mathrm{C}, \mathrm{B}$, and $\mathrm{N}$ atoms centered around such $\mathrm{C}_{2} \mathrm{BN}$ groupings, with a $\mathrm{B} / \mathrm{N}$ ratio close to 2 and a maximum number of stabilizing graphitic C-C bonds. The result of this search is the following elementary "cell"

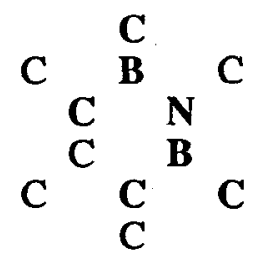

which is built from two $\mathrm{C}_{2} \mathrm{BN}$ groups with one common $\mathrm{N}$ atom. This arrangement is compatible with all the types of bonding which were identified by XPS and the corresponding $\mathrm{B} / \mathrm{N}$ ratio is exactly 2 .

Figure 4 shows how this cell can be used for generating a whole graphitic plane : in the upper part of the figure the orientation of the BNB group is kept constant, while it is random in the lower part. Both arangements correspond to the same overall chemical composition, $\mathrm{C}_{5} \mathrm{~B}_{2} \mathrm{~N}$, which was found to be the "focal point" of the C domain in Figure 1 . Changes can easily be introduced in these $\mathrm{C}_{5} \mathrm{~B}_{2} \mathrm{~N}$ generated structures, which lead to slightly different compositions, either with an excess of carbon or with $B / N$ ratios higher than 2 (see ref [12]). All compositions of the $\mathrm{C}$ domain (Figure 1) can thus be obtained .

It is more doubtful that such regular arrangements exist in the A domain, where a smaller carbon content would lead to an increased concentration of less stable N-N and B-B bonds, but it is very likely that the $\mathrm{C}_{2} \mathrm{BN}$ group still constitutes the basis of the solid solution structure, as evidenced by the XPS spectra (Table 1) showing a high occurrence of $\mathrm{C}_{2} \mathrm{~N}$ environments (at $-1,8 \mathrm{eV}$ ) for the $\mathrm{B}$ atoms. These $\mathrm{C}_{2} \mathrm{BN}$ groups may then be considered as bondings between boron nitride and carbon domains which are the main constituents of these materials.

\section{(5) Thermal stability and "graphitization" of C domain films .}

The effects of heat-treatments on the solid solutions of the $\mathrm{C}$ domain have been studied . It must be remembered that the as-deposited samples are already fairly well twodimensionally crystallized : there are no obvious modifications of the graphitic component of the diffractogram up to $2000^{\circ} \mathrm{C}$. Some $\mathrm{B}_{13} \mathrm{C}_{2}$ lines appears slightly in the $\mathrm{X}$-ray diffractogram of $1700^{\circ} \mathrm{C}$ heat-treated samples and they remain visible up to $2500^{\circ} \mathrm{C}$. Only above $2000^{\circ} \mathrm{C}$ does a significant mass loss occur, indicating the progressive driving out of nitrogen . From $2000^{\circ} \mathrm{C}$ upwards, the sample is a mixture of carbon and boron carbide, resulting from the reaction of carbon and boron nitride and a very remarkable result is the complete graphitization of the carbon achieved at a temperature as low as $2300^{\circ} \mathrm{C}$.

\section{(6) Other properties}

The density of the deposits was found to be 1.89 for the A domain and 2.135 for the films of the $\mathrm{C}$ domain. These as-deposited $\mathrm{BCN}$ solid solutions are denser than both pyrolitic carbons and pyrolitic boron nitride deposited at the same temperature.

Preliminary electrical conductivity measurements were performed on some films between 77 and $300 \mathrm{~K}$. The room-temperature values increase from 3 to $10^{4} \Omega^{-1} \mathrm{~m}^{-1}:$ this is in the range expected for carbon materials deposited or heat-treated at $700-900^{\circ} \mathrm{C}$. The deposits of the $\mathrm{C}$ domain are more conductive by at least a factor 50 and often a factor 1000 than the $\mathrm{A}$ samples . All the samples show a conductivity $\sigma$ increasing with temperature. The log $\sigma \mathrm{vs.} 1 / \mathrm{T}$ plots usually consist of two straight-line segments, suggesting both an extrinsic and an intrinsic 
semi-conductivity. The energy gaps are in the range $10^{-3}-10^{-2}$ (intrinsic) and $10^{-4}-10^{-2} \mathrm{eV}$ (extrinsic). No correlation was observed between these values and the composition.

\section{CONCLUSIONS}

New materials have been obtained as dense, smooth films by CVD in two domains of the B-C-N composition diagram. The carbon-rich domain exhibits a graphite turbostratic structure with a well-developed two-dimensional crystalline order greater than graphitizable pyrocarbons heat-treated at $2000^{\circ} \mathrm{C}$ and a coherence length of $20 \mathrm{~nm}$. These coatings are single-phase materials and the existence of bondings between all the elements is confirmed by XPS. The composition of these films is described satisfactorily by the $\mathrm{C}_{5} \mathrm{~B}_{2} \mathrm{~N}$ stoichiometry and structural disorder can account for the existence of a domain of solid solution. Low carbon content solid solutions are also obtained and can be considered as nearly amorphous materials.

Both kind of materials exhibit similar behavior with respect to heat treatment. No significant mass-loss is observed at $1700^{\circ} \mathrm{C}$ and carbon graphitization is complete at $2500^{\circ} \mathrm{C}$. A solid state reaction is responsible for the vaporization of nitrogen over $2000^{\circ} \mathrm{C}$ leading to an end product which is a mixture of graphite and boron carbide.

\section{Acknowledgements;}

The authors are very grateful to Dr. C Quet (Elf Aquitaine - Groupement de Recherche de Lacq), who performed the XPS studies and helped, with Pr. Tran Minh of University Claude Bernard (Lyon), in their interpretation.

\section{REFERENCES}

-1) A.R.BADZIAN, S.APPENHEIMER, T.NIEMYSKY, E.OLKUSNIK, GLASKI

F.A.(Ed) Proc. of The III Intern. Conf. on CVD(1972) Salt Lake City USA, P.747-753

-2) S.H.CHEN, R.J.DIEFENDORF, Proceedings of the Third Int. Carbon Conf., Baden-Baden, FRG, 1980, P.45-46, (1980)

-3)R.B.KANER, J.KOUVETAKIS, C.E.WARBLE, M.L.SATTLER, N.BARTLETT, Mat.Res.Bull., VOL.22, P.399-404, (1987)

-4) J KOUVETAKIS, T SASAKI, C SHEN, R HAGIRAWARA, M LERNER, K.M. KRISHNAN, N.BARTLETT, Synthetic Metals, VOL.34, P.1-9, (1989)

5) A.W.MOORE, Proc. XVIIIth Intern. Conf. on carbon p.253

6) A.W.MOORE et al , J.Appl.Phys., VOL.65, N¹2, P.5109-5118, (1989)

7) T.M.BESMANN, J.Am.Ceram.Soc., VOL.73, N8, P.2498-2501, (1990)

8) L.MAYA, L.A.Harris, J.Am.Ceram.Soc., VOL.73, N7, P.1912-1916, (1990)

9) F.SAUGNAC, F.TEYSSANDIER, A.MARCHAND, To be published in J. Chim Phys

10) N.BARTLETT, Private communication

11) P.LOLL, Thesis Bordeaux I University (1976)

12) F.SAUGNAC, F.TEYSSANDIER, A.MARCHAND, To be published in J. Amer Ceram. Soc.

13) A.Y.LIU, R.M.WENTZCOVITCH, M.L.COHEN, Phys.Rev.B, VOL.39, N³, P.1760-1765, (1989) 


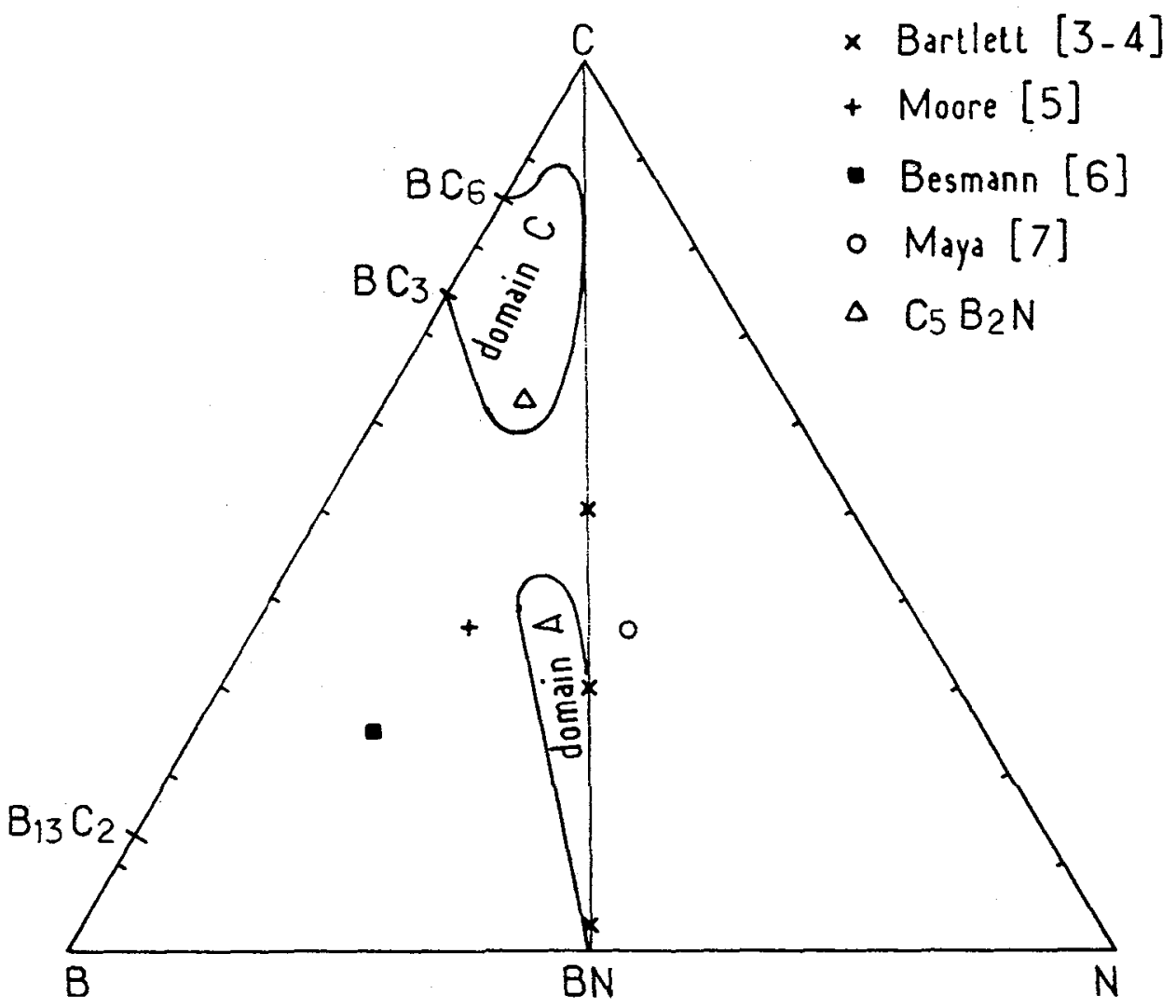

Figure 1: B-C-N composition diagram.

Table 1

General summary of the ESCA spectra analysis of A and C films (oxygen not included)

\begin{tabular}{|c|c|c|c|c|}
\hline \multicolumn{2}{|c|}{$\begin{array}{l}\text { Element and } \\
\text { type of bond }\end{array}$} & Energy shift (eV) & $\begin{array}{l}\text { \% type of bond } \\
\text { Domain A }\end{array}$ & $\begin{array}{l}\text { \% type of bond } \\
\text { Domain C }\end{array}$ \\
\hline Boron & B-N & 0 & $65 \%$ & $20-35 \%$ \\
\hline Boron & $?$ & -1.8 & $20-30 \%$ & $45-80 \%$ \\
\hline Carbon & C-C & 0 & $68.80 \%$ & $50.75 \%$ \\
\hline Carbon & $\mathrm{C}-\mathrm{N}$ & +0.8 to +1.4 & $15-25 \%$ & $5-25 \%$ \\
\hline Carbon & $\mathrm{C} \cdot \mathrm{B}$ & -0.8 to -1.1 & $5.20 \%$ & $15.45 \%$ \\
\hline Nitrogen & $N-B$ & 0 & $65.90 \%$ & $50.80 \%$ \\
\hline Nitrogen & $\mathrm{N}-\mathrm{CB}$ & +1.3 & $10.35 \%$ & $17.40 \%$ \\
\hline
\end{tabular}




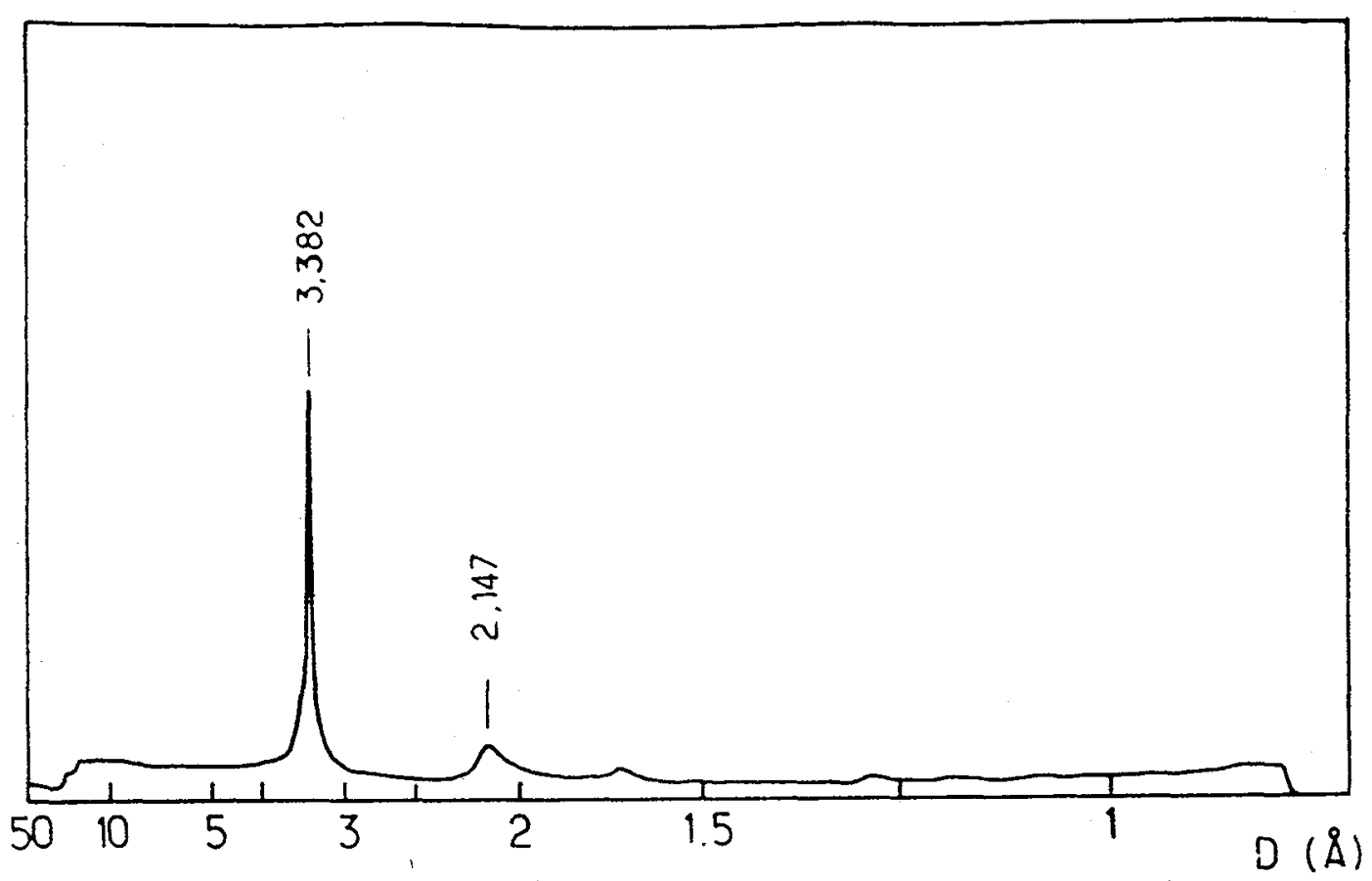

Figure 2: X-ray diffraction pattern of materials from domain $\mathrm{C}$.

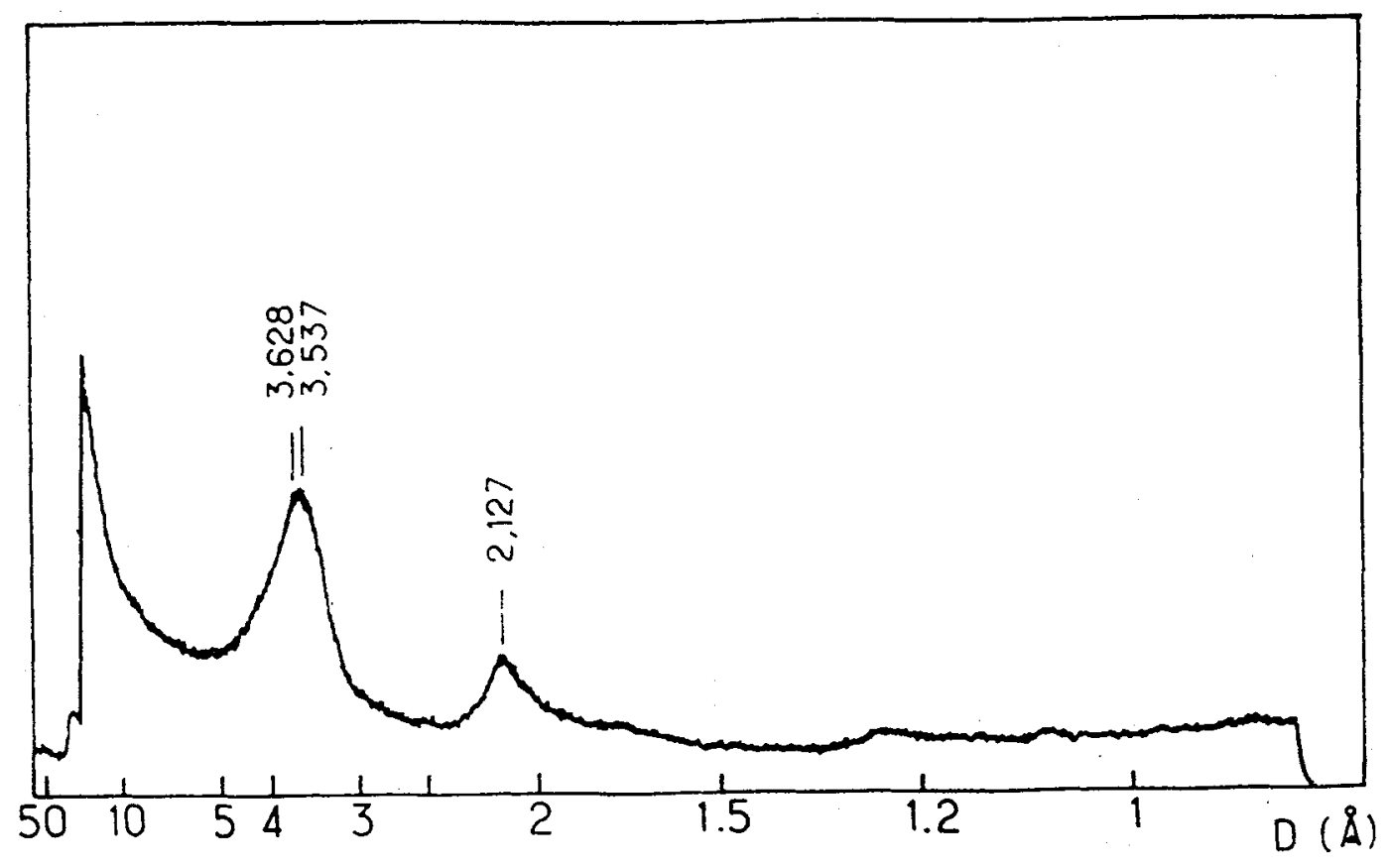

Figure 3: X-ray diffraction pattern of materials from domain A. 


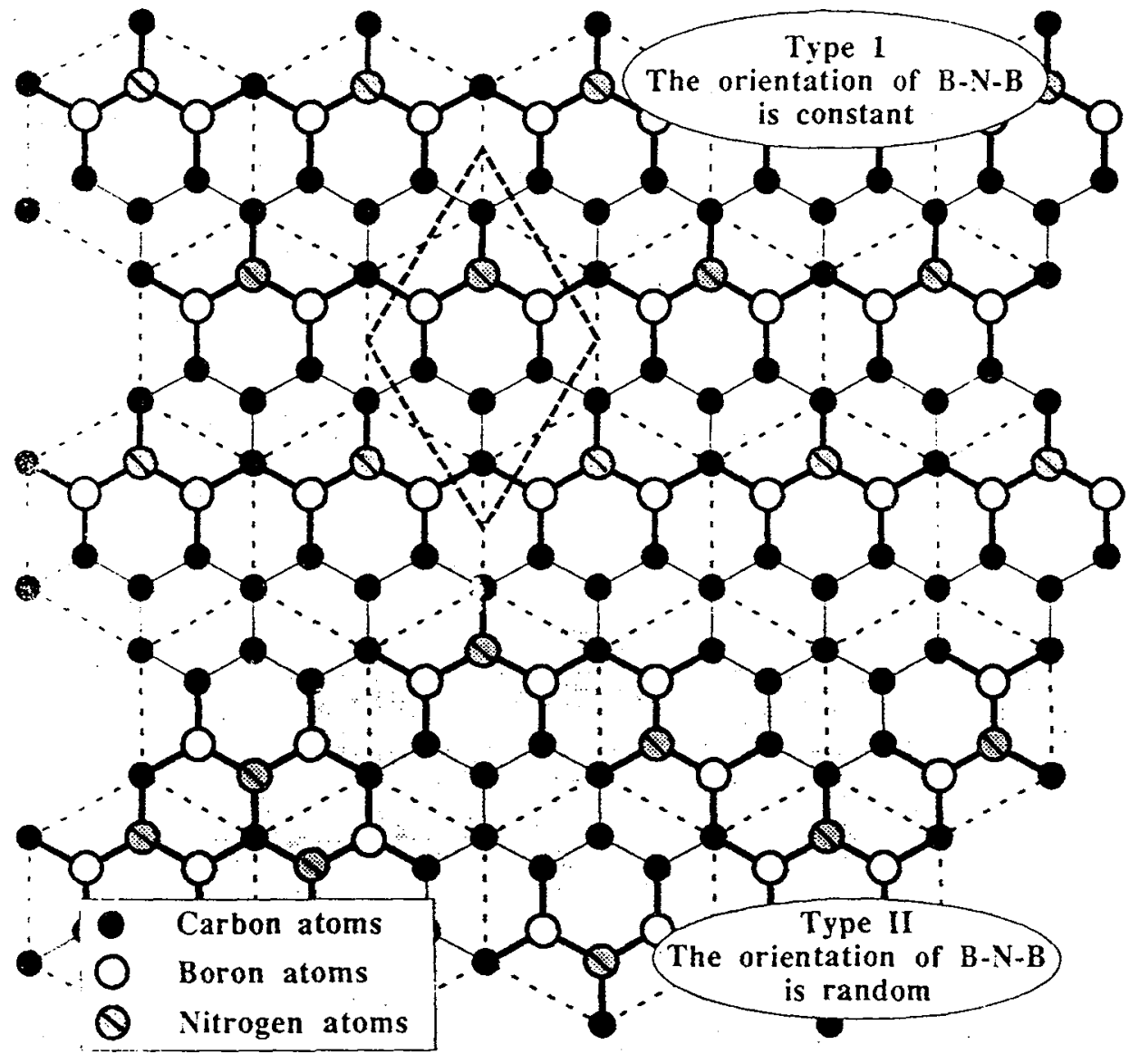

Figure 4: Suggested structures of the graphitic layers. 